\title{
DETERMINATION OF 70 KDA PROTEINS FOR DIFFERENT TEMPERATURES IN CATTLE OOCYTES MATURED IN VITRO
}

\author{
Leyla BENER ${ }^{1 *}$, Mehmet KURAN² \\ ${ }^{1}$ Akdeniz University, Faculty of Agriculture, Department of Agricultural Biotechnology, 07059, Antalya, Turkey \\ ${ }^{2}$ Ondokuz Mayıs University, Faculty of Agriculture, Department of Agricultural Biotechnology, 55139, Samsun, \\ Turkey
}

Received: July 04, 2019; Accepted: August 04, 2019; Published: October 01, 2019

\begin{abstract}
This study was conducted to determine the effect of 36.5 (low) or $38.5^{\circ} \mathrm{C}$ (conventional) culture temperatures during in vitro maturation (IVM) on $70 \mathrm{kDa}$ proteins in cattle oocytes. In the study, cattle cumulus-oocyte complexes (COC) were subjected to IVM in bicarbonate-buffered TCM-199 supplemented with 10\% FCS for 22 hours with a humidified 5\% $\mathrm{CO} 2$ in air at either 36.5 or $38.5^{\circ} \mathrm{C}$ culture temperatures. Maturation of COCs was determined according to fully cumulus expansion at the end of IVM. The cumulus cells of matured COCs were removed by vortexing in TCM-199 with HEPES buffered TCM-199 containing 0.1\% hyaluronidase enzyme. Following, denuded oocytes were washed in $9.6 \%$ phosphate-buffered saline (PBS) solution for protein isolation. Denuded oocytes ( $\mathrm{n}=100$ for both groups) were centrifuged for $5 \mathrm{~min}$ at $300 \mathrm{~g}$ at $4{ }^{\circ} \mathrm{C}$ for PBS removed than the lysis buffer (100 $\mu \mathrm{l}$ ) was added and shake $15 \mathrm{~min}$ on ice for 30 minutes. For protein isolation, the protein was centrifuged again at 13,000 g for 5 minutes and the protein samples were stored at $-20^{\circ} \mathrm{C}$. To increase the concentration of isolated protein samples, the samples were frozen at $80{ }^{\circ} \mathrm{C}$ for 24 hours and lyophilized at $0.140 \mathrm{hPa}$ in a lyophilizer. Lyophilized protein samples were stored at $-20^{\circ} \mathrm{C}$ until SDS-PAGE analysis. The level of $70 \mathrm{kDa}$ proteins in oocytes was determined by SDS-PAGE method. There were no significant differences between low $(81.11 \%)$ or conventional $(84.41 \%)$ incubation temperatures in IVM in terms of full cumulus expansion. The $70 \mathrm{kDa}$ proteins band size in SDS-PAGE polyacrylamide gel image of cattle oocytes maturated at low culture temperature was weak compared to cattle oocytes maturated at conventional culture temperature. The results of this study may show that low incubation temperature during IVM decreases the amount of $70 \mathrm{kDa}$ proteins in cattle oocytes.
\end{abstract}

Keywords: Oocyte, Maturation, Culture temperature, 70 kDa Proteins, Cattle

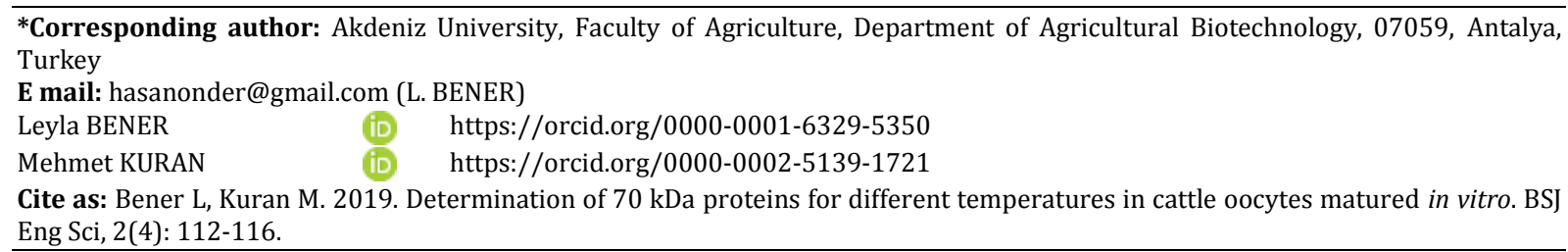
Eng Sci, 2(4): 112-116.

\section{Introduction}

It has been studied for a long time to understand effect heat stress on mature and immature cattles oocytes and also it caused to infertility (Ispada et al., 2018). Cattle oocytes are susceptible to environmental condition factors such as heat stress, temperature and humidity 
(Badinga et al., 1993; Al-Katanani et al., 2001). In vitro embryo production experiments have been carried out in cattle, but this reproductive biotechnology technique is not yet satisfactory to obtain sufficient quantity of good quality transferable embryos (Pfeifer et al., 2008; Koçyiğit et al., 2015). In vitro production of the cattle embryo is affected by many factors (Camargo et al., 2006). One of the basic factors is essential culture conditions of the oocyte during in vitro maturation (IVM) for normal maturation (Cetica et al., 2001). Maturating oocytes (Roth and Hansen 2004; Sen, 2014) in in vitro at high temperature (Lánská et al., 2006) $\left(41^{\circ} \mathrm{C}\right)$ were initiated cellular and molecular changes in the oocyte that causing to the decreased potential of development (Ispada et al., 2018). During maturation 12-14 h heat shock interrupted oocyte microtubule and microfilament texture (Roth and Hansen 2005) and spindle positioning (Ju et al. 2005), diminished nuclear maturation (Roth and Hansen 2005; Rodrigues et al. 2016), affection distribution of cortical granule (Maya-Soriano et al. 2013) and reducing mitochondrial function in oocyte (Nabenishi et al. 2012). Various approaches have been employed to improve maturation and developmental competence of cattle oocytes following in vitro fertilization (KatskaKsiazkiewicz and Alm, 2005; Cevik et al., 2014). In vitro maturation of cattle oocytes has been studied with different supplementation to culture media such as follicular fluid, co-culture (Moulavi et al., 2006), growth factors or gonadotropic hormones (Cevik et al., 2011). However, developmental competence of cattle oocytes not only depends on the composition of the culture media but also incubation conditions such as atmospheric condition, humidity and temperature (Leese et al., 2008). IVM of cattle oocytes are performed at $38^{\circ} \mathrm{C}$ to $39^{\circ} \mathrm{C}$, as this temperature is close to the rectal temperature in cattle (Shi et al., 1998). However, previous studies demonstrated that the temperature in preovulatory follicles is 1.5 to $2^{\circ} \mathrm{C}$ cooler than their adjacent stroma in cattle (Hunter, 2005). The existence of follicular cooling raises the question of whether oocytes develop advantageously at lower temperatures. The reduced temperature might be required for successful oogenesis or oocyte maturation, for subsequent embryonic or fetal development (Hunter et al. 2006).

Heat shock proteins (HSPs), are an protein group that is express when cells are exposed to high temperatures (Aufricht, 2005). The phenomenon heat shock response that leads to a dramatic increase HSPs, are often regulated by the heat shock factor (Morimoto and Santoro, 1998; Sarge et al., 2009). HSP70 is the most important and well-studied protein of all HSP family/families that protect cells, tissues and whole organisms from severe thermal stress (Gao et al., 2014). HSP7 0 can be expressed in the cell by many stress such as infections other than heat, dehydration, treatment with toxic agents, and ultraviolet light (Morimoto and Santoro, 1998, Aufricht, 2005, Petrof et al., 2005). However, high levels of HSP70 expression probably impose costs on individuals exposed to thermal stress by influencing their fecundity, growth or survival (Sørensen et al., 2003; Hamdoun et al., 2003; Karl et al., 2009). Most of these studies infer links between the high expression of HSP70 and thermal adaptation by comparing HSP70 and heat tolerance of animals from different seasons or from different thermal environments (Gao et al., 2014).

The best protected and most studied group in organisms is the $70 \mathrm{kDa}$ heat shock protein family (Morimoto et al., 1986; Feige et al., 1996). The 70-kD heat shock proteins have been studied in different animal models, including (Bernardini et al., 2003) cattle oocytes (Camargo et al., 2006) and embryos (Tavares et al., 2005).

The aim of the present study was, therefore, to determine the effect of 36.5 (low) or $38.5{ }^{\circ} \mathrm{C}$ (conventional) culture temperatures during in vitro maturation (IVM) on $70 \mathrm{kDa}$ proteins in cattle oocytes.

\section{Material and Method}

\subsection{Oocyte Collection}

All chemicals and media used in this study were purchased from Sigma-Aldrich, Turkey. In the present study, cattle ovaries were collected from a local slaughterhouse and transported to the laboratory in a thermos filled with physiological saline solution $(0.9 \%$ $\mathrm{w} / \mathrm{v} \mathrm{NaCl}$ ) containing $0.1 \mu \mathrm{l} / \mathrm{mL}$ antibiotic-antimycotic solution (10.000 IU penicillin, $10 \mathrm{mg}$ streptomycin and 25 $\mu \mathrm{g}$ amphotericin B per $\mathrm{ml}$ ) at $34.0 \pm 2.0^{\circ} \mathrm{C}$ within $3 \mathrm{~h}$ after slaughter. Cumulus-oocyte complexes were recovered from follicles 2-8 $\mathrm{mm}$ in diameter by aspiration, using an eighteen-gauge needle fixed to ten $\mathrm{ml}$ syringe and then cumulus-oocyte complexes were washed two times with Hepes-buffered medium-199. Cumulus-oocyte complexes were assessed morphologically and only oocytes with compact, intact cumulus cells around and homogeneous cytoplasm were selected for maturation (Sen, 2015).

2.2. Preparation Culture Medium and Heat Treatments

A total of 400 cumulus-oocyte complexes were subjected to in vitro maturation. Maturation medium was prepared according to Cevik et al. (2011). Cumulus-oocyte complexes were separately placed in $500 \mu \mathrm{l}$ of maturation medium covered with $300-\mu \mathrm{l}$ mineral oil in four-well dishes approximately thirty cumulus-oocyte complexes per well. Maturation medium was sodium bicarbonatebuffered Medium 199 (M4530; Sigma, Turkey) containing Earle's salts and L-glutamine supplemented with 5.5 $\mu \mathrm{g} / \mathrm{mL}$ sodium pyruvate, $1 \% \mathrm{v} / \mathrm{v}$ antibiotic-antimycotic solution and $10 \% \mathrm{v} / \mathrm{v}$ (growth facrors) heat-inactivated fetal bovine serum.

Selected cumulus-oocyte complexes were matured for 22 hours in a humidified atmosphere of 5\% $\mathrm{CO} 2$ in the air at $36.5{ }^{\circ} \mathrm{C}$ (low) or $38.5{ }^{\circ} \mathrm{C}$ (conventional). Cumulus cell expansion of cumulus-oocyte complexes at both culture temperatures were evaluated at the end of maturation period under a stereomicroscope. Cumulus-oocyte complexes with fully expanded cumulus cell layer 
considered as maturated oocytes.

The cumulus cells of matured COCs were removed by vortexing in TCM-199 with hepes buffered TCM-199 containing $0.1 \%$ hyaluronidase enzyme. Following, denuded oocytes were washed three times in $9.6 \%$ phosphate-buffered saline (PBS) solution for protein isolation. Denuded oocytes ( $\mathrm{n}=100$ for both groups) were centrifuged for $5 \mathrm{~min}$ at $300 \mathrm{~g}$ at $4{ }^{\circ} \mathrm{C}$ to remove PBS. The lysis buffer $(100 \mu \mathrm{l})$ was then added and shake $15 \mathrm{~min}$ on ice for 30 minutes.

\subsection{Isolation Protein and Lyophilization}

For protein isolation, the protein was centrifuged again at $13,000 \mathrm{~g}$ for 5 minutes, and the protein samples were stored at -20 untill SDS-PAGE gel electrpphoresis. To increase the concentration of isolated protein samples, firstly the samples were frozen at $-80^{\circ} \mathrm{C}$ for 24 hours and secondly lyophilized at $0.140 \mathrm{hPa}$ in a lyophilizer. Lyophilized protein samples were stored at $-20{ }^{\circ} \mathrm{C}$ until SDS-PAGE analysis. The level of $70 \mathrm{kDa}$ proteins in oocytes was determined by SDS-PAGE method.

\subsection{Statistical Analysis}

Treatment effects (temperature) on cumulus cell expansion of cattle oocytes were analyzed by chi-square $(\chi 2)$ test. Statistical analyses were performed by the SPSS
17.0 package program (SPSS, Chicago, IL, USA).

\section{Results and Discussion}

Maturation ratio according to cumulus expansion of cattle oocytes matured in vitro either at $36.5^{\circ} \mathrm{C}$ or $38.5^{\circ} \mathrm{C}$ maturation temperatures were presented in Table 1. There were no significant differences between low $(81.11 \%)$ or conventional $(84.41 \%)$ incubation temperatures in IVM in terms of whole cumulus expansion. The results of the present study showed that culture temperature during in vitro maturation had no effect on cumulus cell expansions of cattle oocytes.

Ye et al. (2007) suggested that lower follicular ambient temperature is advantageous to complete oocyte maturation or development, within the follicular microenvironment. The results of the present study show that culture temperature during in vitro maturation had no effect on cumulus cell expansions of cattle oocytes. Similar to the results of our study, previous studies have shown that low incubation temperature during IVM did not affect the rate of cumulus expansion (Shi et al., 1998; Lenz et al., 1983; Ravindranatha et al., 2003; Sen and Kuran, 2018).

Table 1. Maturation ratio according to cumulus expansion of cattle oocytes matured in vitro either at $36.5^{\circ} \mathrm{C}$ or $38.5^{\circ} \mathrm{C}$ maturation temperatures.

\begin{tabular}{lccccc}
\hline $\mathrm{CT}\left({ }^{\circ} \mathrm{C}\right)$ & Total oocytes & Matured oocytes & Matured oocytes ratio (\%) & Std Error & $\mathrm{P}$ \\
\hline $36.5 \mathrm{C}^{\circ}$ & 1393 & 1121 & 81.11 & 3.41 & 0.554 \\
$38.5 \mathrm{C}^{\circ}$ & 1501 & 1325 & 84.41 & 2.26 & \\
\hline
\end{tabular}

CT= culture temperatures

SDS-PAGE polyacrylamide gel image of cattle oocytes maturated at $36.5{ }^{\circ} \mathrm{C}$ (low) or $38.5{ }^{\circ} \mathrm{C}$ (conventional) culture temperatures is present Figure 1.

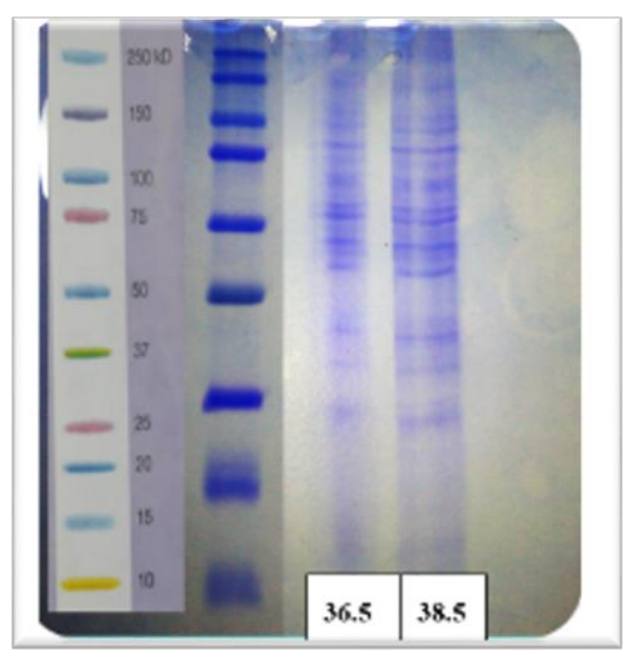

Figure 1. SDS-PAGE polyacrylamide gel image of cattle oocytes maturated at low or conventional culture temperatures.
Among the major heat shock proteins produced by most cells are those that belong to $70 \mathrm{kDa}$ heat shock proteins family (Parsell and Lindquist, 1993). $70 \mathrm{kDa}$ heat shock proteins protect cells against adverse effects of stress (Hendry and Kola, 1991), and function in the absence of stress as a molecular chaperone (Becker and Craig, 1994). In mammals, cytosolic members of the $70 \mathrm{kDa}$ heat shock proteins family appear in two isoforms: a constitutively synthesised variant and a highly heatinducible form. These two proteins exhibit a high degree of relatedness, although encoded by distinct genes (Welch and Feramisco, 1982). Experiments utilising metabolic labelling with 35S-amino acids and twodimensional gel electrophoresis have indicated that maturing cattle oocytes synthesise $70 \mathrm{kDa}$ heat shock proteins but the magnitude of synthesis is not increased upon heat shock (Edwards and Hansen, 1997). By the 2cell stage, however, heat shock increases the synthesis of $70 \mathrm{kDa}$ heat shock proteins. The heat-inducibility of 70 $\mathrm{kDa}$ heat shock protein genes at the 2-cell stage occurs even in the presence of $\alpha$-amanitin (Edwards et al., 1997), suggesting either that the increase in $70 \mathrm{kDa}$ heat 
shock protein synthesis is regulated posttranscriptionally or, as with Drosophila (Gilmour and Lis, 1986), that RNA polymerase II is bound to the promoter before heat shock and thereby prevents the inhibitory effect of $\alpha$-amanitin on transcription.

In previous studies, Kawarsky and King, (2001) determined that heat stress of HSP70 mRNA can be transcribing under control conditions in early embryonic period during in vitro maturation of cattle oocytes. As a result of confocal laser scans, it was reported that hsp70 protein was not affected by high temperature exposure in the mature and immature oocyte ooplasm of oocytes and embryos and this protein may be related to meiotic spindle (Kawarsky and King, 2001). Therefore, in our study maturation cattle oocyte at low incubation temperature $\left(36.5{ }^{\circ} \mathrm{C}\right)$ and conventional culture temperature $\left(38.5^{\circ} \mathrm{C}\right)$ in in vitro may be a reason for the low amount of protein in $70 \mathrm{kDa}$.

In the present study, the $70 \mathrm{kDa}$ proteins band size in SDS-PAGE polyacrylamide gel image of cattle oocytes maturated at low culture temperature was weak compared to cattle oocytes maturated at conventional culture temperature. The results of this study may show that low incubation temperature $\left(36.5{ }^{\circ} \mathrm{C}\right)$ during IVM did not have any effects on cumulus expansion and low incubation temperature during IVM decrease the amount of $70 \mathrm{kDa}$ proteins in cattle oocytes. In the future, expression studies can be to describe during the heat stress in the cells. Specificity of the stress response to the cell type can be studied. The effect of nutrient content on oocytes and the synthesis of hsp70 can be investigated.

\section{Conflict of interest}

The authors declare that there is no conflict of interest.

\section{Acknowledgements}

The authors acknowledge the financial support by the Ondokuz Mayis University Scientific Research Projects Coordination Unit (Project no: PYO.ZRT.1904.17.031) to carry out this study. This research was presented as an oral presentation at the International Congress on Domestic Animal Breeding Genetics and Husbandry (ICABGEH-2018) held on 26-28 September 2018 in Antalya.

\section{References}

Al-Katanani YM, Paula-Lopes FF, Hansen PJ. 2002. Effect of season and exposure to heat stress on oocyte competence in Holstein cows. J Dairy Sci, 85(2): 390-396.

Aufricht C. 2005. Heat-shock protein 70: molecular supertool? Pediatr Nephrol, 20: 707-713.

Badinga L, Thatcher WW, Diaz T, Drost M, Wolfenson D. 1993. Effect of environmental heat stress on follicular development and steroidogenesis in lactating Holstein cows. Theriogenology, 39(4): 797-810.

Becker J, Craig EA. 1994. Heat-shock proteins as molecular chaperones. Eur J Biochem, 219: 11-23.
Bernardini C, Fantinati P, Castellani G, Forni M, Zannoni A, Seren E, Bacci ML. 2003. Alteration of constitutive heat sok protein 70 (HSC70) production by in vitro culture of porcine preimplanted embryos. Vet Res Commun, 27(1): 575-578.

Camargo LSA, Viana JHM, Sa WF, Ferreira AM, Ramos AA, Vale Filho VR. 2006. Factors influencing in vitro embryo production. Anim Reprod, 3 (1): 19-28.

Cetica PD, Pintos LN, Dalvit GC, Beconi MT. 2001. Antioxidant enzyme activity and oxidative stress in bovine oocyte in vitro maturation. IUBMB Life, 51(1): 57-64.

Cevik M, Sen U, Kocyigit A, Soydan E, Kuran M. 2011. Effects of serum, gonadotropins, epidermal growth factor and estradiol 17-beta on cumulus expansion and nuclear maturation of bovine oocytes. Kafkas Univ Vet Fak Derg, 17: 1009-1014.

Cevik M, Kocyigit A, Sen U, Kuran M. 2014. Can commercial human embryo culture media be used in bovine embryo culture? Kafkas Univ Vet Fak Derg, 20(1): 149-153.

Edwards JL, Ealy AD, Monterroso VH, Hansen PJ. 1997. Ontogeny of temperature-regulated heat shock protein 70 synthesis in preimplantation bovine embryos. Mol Reprod Dev, 48: 25-33.

Edwards JL, Hansen, PJ. 1997. Differential responses of bovine oocytes and preimplantation embryos to heat shock. Mol Reprod Dev, 46: 138-45.

Feige U, Morimoto R I, Yahara I, Polla B. 1996. Stress inducible cellular responses. Birkhauser Verlag, 77.

Gao J, Zhang W, Dang W, Mou Y, Gao Y, Sun BJ, Du WG. 2014 Heat shock protein expression enhances heat tolerance of reptile embryos. Proc Biol Sci, 281(1791): 1-10.

Gilmour DS, Lis JT. 1986. RNA polymerase II interacts with the promoter region of the noninduced hsp70 gene in Drosophila melanogaster cells. Mol Cell Biol, 6: 3984-3989.

Hamdoun AM, Cheney DP, Cherr GN. 2003. Phenotypic plasticity of HSP70 and HSP70 gene expression in the Pacific oyster (Crassostrea gigas): implications for thermal limits and induction of thermal tolerance. Biol Bull, 205: 160-169.

Hendry J, Kola I. 1991. Thermolability of mouse oocytes is due to the lack of expression and/or inducibility of hsp70. Mol Reprod Dev, 28: 1-8.

Hunter RHF, Einer-Jensen N, Greve T. 2006 Presence and significance of temperature gradients among different ovarian tissues. Microsc Res Tech, 69: 501-507.

Hunter RHF. 2005. The Fallopian tubes in domestic mammals: how vital is their physiological activity? Reprod Nutr Dev, 45: 281-290.

Ispada J, Rodrigues TA, Risolia PHB, Lima RS, Gonçalves DR, Rettori D, Paula-Lopes FF. 2018. Astaxanthin counteracts the effects of heat shock on the maturation of bovine oocytes. Reprod Fertil Develop, 30(9): 1169-1179.

Ju JC, Jiang S, Tseng JK, Parks JE, Yang X. 2005. Heat shock reduces developmental competence and alters spindle configuration of bovine oocytes. Theriogenology, 64(8): 16771689.

Karl I, Sorensen JG, Loeschcke V, Fischer K. 2009. HSP70 expression in the copper butterfly Lycaena tityrus across altitudes and temperatures. J Evol Biol, 22: 172-178.

Katska-Ksiazkiewicz L, Alm H. 2005. Effect of culture methods on cumulus and oocyte morphology and meiotic competence of bovine oocytes from early antral follicles. Arch Tierz Dummerstorf, 48: 562-571.

Kawarsky SJ, King WA. 2001. Expression and localisation of heat shock protein 70 in cultured bovine oocytes and embryos. Zygote, 9(1): 39-50.

Kocyigit A, Cevik M, Sen U, Kuran M. 2015. The effect of macromolecule and growth factors combinations on in vitro 


\section{Black Sea Journal of Engineering and Science}

development of bovine embryos. Turkish J Vet Anim Sci, 39: 308-313.

Lánská V, Chmelíková E, Sedmíková M, Petr J, Rajmon R, Ješeta M, Rozinek J. 2006. Expression of heat shock protein70 in pig oocytes: Heat shock response during oocyte growth. Anim Reprod Sci, 96(1-2): 154-164.

Leese HJ, Baumann CG, Brison DR, McEvoy TG, Sturmey R.G. 2008. Metabolism of the viable mammalian embryo: quietness revisited. Molec Human Reprod, 14: 667-672.

Lenz RW, Ball GD, Leibfried ML, Ax RL, First NL. 1983. İn vitro maturation and fertilization of bovine oocytes are temperature dependent processes. Biol Reprod, 29: 173-179.

Maya-Soriano MJ, Taberner E, López-Béjar M. 2013. Retinol improves in vitro oocyte nuclear maturation under heat stress in heifers. Zygote, 21(4): 377-384.

Morimoto RI, Hunt C, Huang S Y, Berg L, Banerji S. 1986. Organization, nucleotide sequence, and transcription of the chicken HSP70 gene. J Biol Chem, 261: 12692-12699.

Morimoto RI, Santoro MG. 1998. Stress-inducible responses and heat shock proteins: new pharmacologic targets for cytoprotection. Nat Biotechnol, 16: 833-838.

Moulavi F, Hosseini SM, Ashtiani SK, Shahverdi A, Nasr-Esfahani MH. 2006. Can Vero cell co-culture improve in-vitro maturation of bovine oocytes? Reprod Biomed Online, 13: 404-411.

Nabenishi H, Takagi S, Kamata $H$, Nishimoto $T$, Morita $T$, Ashizawa K, Tsuzuki Y. 2012. The role of mitochondrial transition pores on bovine oocyte competence after heat stress, as determined by effects of cyclosporin A. Molec Reprod Develop, 79(1): 31-40.

Parsell DA, Lindquist S. 1993. The function of heatshock proteins in stress tolerance: degradation and reactivation of damaged proteins. Annu Rev Genet, 27: 437-96.

Petrof EO, Ciancio M, Chang EB. 2004. Role and regulation of intestinal epithelial heat shock proteins in health and disease. Chin J Dig Dis, 5: 45-50.

Pfeifer LFM, Schneider A, Correa MN. 2008. Factors that affect the in vitro production of bovine embryos: A review Rev Colomb Cienc Pecu, 21: 109-120.

Ravindranatha BM, Nandi S, Raghu HM, Reddy SM. 2003. İn vitro maturation and fertilization of buffalo oocytes: effects of storage of ovaries, IVM temperatures, storage of processed sperm and fertilization media. Reprod Domest Anim, 38: 2126.

Roth Z, Hansen PJ. 2004. Involvement of apoptosis in disruption of developmental competence of bovine oocytes by heat shock during maturation. Biol Reprod, 71(6): 1898-1906.

Roth Z, Hansen PJ. 2005. Disruption of nuclear maturation and rearrangement of cytoskeletal elements in bovine oocytes exposed to heat shock during maturation. Reprod, 129(2): 235-244.

Sarge KD, Murphy SP, Morimoto RI. 2009. Activation of heat shock gene transcription by Heat Shock Factor 1 involves oligomerization, acquisition of DNA-binding activity, and nuclear localization and can occur in the absence of stress. Mol Cell Biol, 13: 1392-1407.

Sen U, Kuran M. 2018. Low incubation temperature successfully supports the in vitro bovine oocyte maturation and subsequent development of embryos. Asian-Australas J Anim Sci, 31(6): 827-834.

Sen U. 2015. Effects of sperm from different bulls on developmental competence, blastosist quality and cell number of bovine embryos in vitro. Kafkas Univ Vet Fak Derg, 21 (3): 339-344.

Shi DS, Avery B, Greve T. 1998. Effects of temperature gradients on in vitro maturation of bovine oocytes. Theriogenology, 50 : 667-674.

Sørensen JG, Kristensen TN, Loeschcke V. 2003. The evolutionary and ecological role of heat shock proteins. Ecol. Lett. 6: 1025- 1037.

Tavares A, Oliveira de D, Felix Lopes RF, Rodrigues LJ. 2005 Gene expression and developmental competence of bovine embryos produced in vitro under varying embryo density conditions. Theriogenology, 64: 1559-1572.

Welch RJ, Feramisco, JR. 1984. Nuclear and nucleolar localization of the 72000 -dalton heat shock protein in heatshocked mammalian cells. J Biol Chem, 259: 4501-4513.

Ye J, Coleman J, Hunter MG, Craigon J, Campbell KH, Luck MR. 2007. Physiological temperature variants and culture media modify meiotic progression and developmental potential of pig oocytes in vitro. Reprod, 133: 877-886. 